\title{
LITERATURA CORTESANA Y REPRESENTACIÓN POLÍTICO-RELIGIOSA DE CARLOS II DE ESPAÑA: ACADEMIA A QUE DIO ASUNTO LA RELIGIOSA Y CATÓLICA ACCIÓN QUE EL REY, NUESTRO SEÑOR, EJECUTÓ EL DÍA 20 DE ENERO DESTE AÑO DE 1685 (ESTUDIO Y EDICIÓN)
}

\author{
Alain Bègue \\ (FoReLL-CELES XVII-XVIII, Université de Poitiers)
}

\section{RESUMEN}

El sábado 20 de enero de 1685, día de San Sebastián, al prestar ayuda a un sacerdote que transportaba el Santo Viático hacia la morada de un campesino moribundo, Carlos II protagonizó uno de los principales acontecimientos de su reinado. Este episodio contribuyó, quizá como ningún otro, a alimentar el elaborado discurso político-confesional y propagandístico de una monarquía católica en la que la religión se había convertido no sólo en un pilar fundamental, sino también en el verdadero sustento de la identidad política y dinástica de los Habsburgo. De entre cuantas obras literarias y muestras artísticas se produjeron con motivo de la religiosa acción del monarca español cabe destacar una academia literaria, la que albergó en su casa Pedro de Arce, regidor de la villa de Madrid. Mediante su participación en esta reunión literaria, el selecto grupo de poetas -reconocidos o no-que la integraban quiso poner de manifiesto su particular adhesión a la monarquía del último representante de la Casa de Austria. Nuestro trabajo ofrece un detenido estudio, así como la edición crítica de esta original y excepcional academia literaria.

PALABRAS CLAVE Academias literarias, Barroco, Carlos II, Literatura cortesana, Poesía de elogio

\section{COURTESAN LITERATURE AND POLITIC-RELIGIOUS REPRESENTATION OF CHARLES II OF SPAIN: ACADEMIA A QUE DIO ASUNTO LA RELIGIOSA Y CATÓLICA ACCIÓN QUE EL REY, NUESTRO SEÑOR, EJECUTÓ EL DÍA 20 DE ENERO DESTE AÑO DE 1685 (STUDY AND EDITION)}

\begin{abstract}
On Saturday, January 20th, 1685, on St. Sebastian's day, when he helped a priest carrying the Viaticum to the abode of a dying peasant, Charles II carried out one of the principal events of his reign. This episode contributed, perhaps like no other, to
\end{abstract}


nourishing the elaborate, confessional and propagandistic discourse of a Catholic monarchy in which religion had become not only a fundamental pillar but also in the true sustenance of the political and dynastic identity of the Habsburgs. Among literary works and artistic samples were produced by the religious action of the Spanish monarch include a literary academy, which housed Pedro de Arce, councilor of the villa of Madrid. Through their participation in this literary meeting, the select group of poets - recognized or not - that integrated it wanted to show their particular support to the monarchy of the last representative of the House of Austria. Our paper offers a detailed study, as well as the critical edition of this original and exceptional literary academy.

KEYWORDS: Literary Academies, Barroque, Charles II, Courtesan Literature, Poetry of praise 